\title{
Financial implications of globalization and new technologies Ukraine international relations
}

\author{
Tetyana Calinescu ${ }^{1}$, Ganna Likhonosova ${ }^{1, *}$, and Olena Zelenko ${ }^{2}$ \\ ${ }^{1}$ National Aerospace University "Kharkiv Aviation Institute", Faculty of Software and Business, \\ Finance, accounting and taxation Department, Chkalova 17, 61070 Kharkiv, Ukraine \\ ${ }^{2}$ Volodymyr Dahl East Ukrainian National University, Educational and Scientific Institute of \\ International Relations, International Economy and Tourism Department, 59A Tsentralny Prospect, \\ 93406 Severodonetsk, Ukraine
}

\begin{abstract}
.
Research background: The world will change radically after the COVID2019 pandemic. The transformation of financial globalization is already taking place. It contributes to the emergence of new international relation's forms, institutions, technologies of interaction. All these trends necessitate a revision of the basic Ukraine concepts on convergent integration into the international financial space.

Purpose of the article: To identify effects of financial globalization in Ukraine and characteristics of digital human interaction; to define an expansion of digital health principles for the elimination of the population's cognitive skills atrophy and to offer new information convergence technology, financial autonomy and identity of the country in global financial market.

Methods: The methods of divergence and convergence, rationality and irrationality - to find effective tools for regulating international financial relations in Ukraine; methods of cognitive data analysis - to determine forms, directions of Ukrainian society digital hygiene; conceptualization of consequences and duality of results evaluation - for clarity of reflection of a modern development condition for a society emotional intelligence and levelling of Ukraine dependence on financial hedonism in the world.

Findings \& Value added: This search for regulation methods is based on a hybrid combination of global professional achievements in the regulation of financial markets, author's work, applied projects to stabilize the financial system and priority measures to balance the development of the national economy of Ukraine. This approach will increase the effectiveness of financial relations and solving socio-economic problems at the national and international levels, while ensuring the achievement of national priorities and interests.
\end{abstract}

Keywords: globalization; financial implications; relationship technologies; digital hygiene; national identity

JEL Classification: $F 65 ; M 15 ; P 33$

* Corresponding author: a.likhonosova@gmail.com 


\section{Introduction}

It is commonplace to say now that the world will change radically after the COVID-2019 pandemic. However, some experts argue that the globalization will break and all countries will solve only their own economic and social problems [1], others believe that globalization will only accelerate under the influence of external threats that go far beyond national borders [2]. The European Union is experiencing existential problems for its own security. The UK's exit from the EU, the closure of borders in connection with the COVID2019 epidemic and the impossibility of implementing effective measures of solidarity support in society - all this makes the prospects for the financial well-being of modern society unclear.

In fact, globalization, while making goods less expensive for the average consumer, has further widened the gap between rich and poor. That globalization has contributed to growing economic inequality among about a billion people living in developed countries, said K. Rogoff [3]. Trade competition has hit hard on low-wage workers in some industries. Central banks see their main goal to preserve the issuance of currency, but there have long been other ways of monetary and financial exchange: electronic money and cryptocurrency, the introduction of which has been actively discussed for several years by leading economists with priority.

Typical financial consequences of globalization for Ukraine are [4]: 1) increase in the number of deep systemic shocks and crises in some regions (and territories); 2) structural transformation of the national economy and adaptation mechanism in accordance with changes in global demand; 3) temporary, selective or limited use of protectionism as an adaptive mechanism for the gradual liberalization of the economy; 4) convergence of socioeconomic conditions, factors of mechanisms of development of the country, regions and the global economy in general; 5) convergence of income levels per capita on a global scale; 6) the emergence of new models of economic growth and balanced development, based on new paradigms of financial security.

\section{Methods}

The search for effective methods of regulation is based on the collaboration of authorial and collective projects, which is carried out in the framework of research carried out at the National Aerospace University "Kharkiv Aviation Institute" on "Modern determinants of financial development and accounting in a systemic crisis", which were performed in 20182020 (state registration number 0118U004462).

\section{Results and Discussions}

According to experts [5], the new global economic crisis will not be associated with problems in the financial sector, but will be characterized by prolonged low economic growth and high inflation. Overall production efficiency and productivity around the world will decline. The COVID-2019 global pandemic, launched in 2019, has already given impetus to the reversal of the tangle of globalization.

The positive consequences of financial globalization are that it creates opportunities for almost instantaneous movement of financial resources, which can both maintain the stability of the global financial market and provoke a financial crisis, including in some countries. Today's globalization of financial relations is increasingly virtualizing the world economy, which is very weakly consistent with real economic relations. Johan Graafland, Niels Noorderhaven state that globalization has given way to a new era of stagnation or 
globalization [2]. In other words, there will be no new crisis in the form of a collapse with a subsequent slow recovery. Instead, the economy is facing a new model of international trade, and its novelty is to strengthen economic ties within regional blocs to the detriment of transnational trade. That is, production and marketing chains are increasingly tied to nearby suppliers.

It is safe to say that regional identity comes to the fore. In essence, we are talking about the localization of markets - both production and consumption. Which, of course, creates problems for developing countries that will now have to compete either in the markets of more developed countries or in a limited circle of equals.

Globalization should not result in a drop in living standards. Markets connecting several countries are quite large and may well prosper. Also, one of the consequences of globalization is the strengthening of regional integration, and this will most likely have a short- and medium-term stimulus to development in economic interpretation. In other words, globalization is a pendulum of globalization that rocked back the pendulum from 2020 to the 1990s. Then trade grew as logistics costs fell, communications fell, customs tariffs were cut and the financial sector was liberalized.

On the one hand, globalization is a process that is fairer [6] in relation to countries and peoples that still remain on the periphery. Including to Ukraine. If the government of Ukraine understands the new trend of the world economy in time, the geographical position of the country may well turn the effect of regionalization of the economy in its favor.

Dynamic changes in the world require a rethinking of the new challenges facing national and global economies. It is the harmonization of various mechanisms of regulation and stabilization of economies that will make it possible to carry out structural transformations, reducing or avoiding the financial consequences of globalization. The new paradigm of Ukraine's development envisages measures to overcome the financial consequences of globalization through effective interaction of the banking, insurance, pension systems, stock market and the improved Tax Code [4].

1. Modern instruments of regulation of the banking system of Ukraine should provide for the modernization of the main mission of the National Bank of Ukraine (NBU) to stabilize the national currency (hryvnia), ensure economic growth and development of economic entities; increasing household incomes and restoring public confidence in the banking sector. To this end, it is necessary to: a) adapt the banking system of Ukraine to European norms and standards; b) targeting of banking activities through the use of various instruments to ensure the necessary money supply in relation to the needs of the national economy, the level of lending, preservation and creation of new jobs; c) providing and guaranteeing the deposits of the population that currently lend to modern Ukrainian business and provide resources to meet the needs of balanced economic development; $d$ ) creation of conditions for preferential crediting of small and medium business (especially, in the conditions of the consequences which have developed within the limits of introduction of quarantine on COVID-19). As well as mortgages for individuals (for migrants and combatants in a hybrid war). Quite attractive in this sense are the proposals presented in the report of the "Club of Rome" [7] on the use of soft loans to stimulate the introduction of "green packages" - measures to improve the level and quality of life of society, the creation of additional jobs; e) conducting an information campaign to restore confidence in the banking system of Ukraine by the International Financial Institutions (especially in the context of a change in the leadership of the NBU).

2. Ensuring the effective functioning of the stock market of Ukraine should go through the modernization of market infrastructure, full functioning, encouragement of capital investments and the implementation of sustainable expectations of all participants. The main directions of development should be: 1) ensuring the effective functioning of the national depository and clearing system by merging and consolidating existing depository 
institutions; 2) development and improvement of the securities accounting system based on the introduction of international standards of accounting for property rights; 3) diversification of financial instruments aimed at risk hedging; 4) development of mutual investment institutions as an alternative to financial intermediation and the banking system; 5) strengthening the information support of the national stock market potential in order to form its positive image.

3. The development of the Ukrainian insurance market should be aimed at strengthening the socio-economic, investment and innovation component in the process of modernization, internationalization and transformation of the national economy. This determines such reforms in the insurance system of Ukraine as: a) ensuring equal conditions for all participants and insurance companies, regardless of ownership, size of capital and specialization of insurance activities; b) development of institutions of self-regulation of the insurance market, supervision and limitation of the number of intermediary links; c) introduction of a rating system in accordance with the requirements of the international insurance market; d) stimulating the creation of insurance companies with foreign investment; e) intensification of professional insurance education in the direction of training specialists - insurance agents, underwriters, actuaries, insurance detectives and engineers. To this end, most universities in Ukraine introduce educational programs in finance, banking and insurance, which are aimed at expanding knowledge in the field of insurance.

4. Pension insurance in Ukraine should be comprehensively developed at three levels, namely: solidarity (state), accumulative (mandatory for working citizens) and non-state (voluntary), which will turn personal pension savings into a long-term source of investment resources for the national economy. To this end, it is envisaged: 1) creation of a single state register of pensioners (according to experts, about $20 \%$ of payments from the State Pension Fund is not confirmed by the physical presence of recipients [4];2) reduction of the degree of differentiation between the minimum and maximum possible amounts of pensions; 3 ) introduction of tax incentives for business entities in order to increase pension contributions; 4) elimination of double taxation of individual pension savings of citizens (this applies to the taxation of accumulated income and income received from investing their own pension savings, which according to existing Tax legislation (personal income tax) must be taxed separately). And as one of the measures offered not only in Ukraine but also for all countries of the world who care about the level of pension provision [7]; 5) raising the retirement age, which is carried out by Ukraine through the introduction of new pension reforms and gradually reducing the financial burden on the state to pay pensions under a joint pension system financed by a smaller population in a global negative natural environment, growth and migration of economically active population.

5. The main principle on which the functioning of the Tax System of Ukraine should be focused is the stability of the tax base by: a) maximum simplification of tax administration; b) reduction of the tax burden to a level that makes it economically impractical to evade taxes (according to world tax reporting reports, Ukraine is in the zone of countries with the highest level of tax burden (51.9\%), according to the level of tax burden on the payroll ranks fifth in the world (43.1\%) [4]; c) stimulating economic activity by reducing the tax base of profits reinvested in the development of high-tech and energy-saving industries. However, within the globalized economic system, members of the "Club of Rome" recommended [7]: d) to increase taxes on large corporations, for this purpose some international cooperation is possible to limit or expand tax horizons, including the financial and banking sectors of economies; deprivation or introduction of certain privileges regarding the taxation of financial transactions, value added, commercial real estate, dividend tax, environmental pollution, negative externalities that affect the activities of such companies, such as the use of fossil fuels, fuels, raw materials that add greenhouse gas emissions ; e) a gradual increase in inheritance taxes (even up to $100 \%$ ) through the 
revision by governments of property laws, based on the beliefs of Theodore Roosevelt, Adam Smith, Thomas Payne and Locke [7], that each generation cannot bind itself and have no right to property of its descendants, because the expansion of property rights is quite unnatural. Therefore, such taxes should eliminate such social anomalies; Another mechanism for reforming the tax system, which is currently being discussed in recognized international economic and financial sources $[8,9,10,11]$ is e) the introduction of progressive taxation $[9,10]$, which concerns not only the introduction of a progressive scale of tax revenues [8], but also the progress of views on taxes on the regulation of interest rates at the societal level [9]; g) focus on a differential approach to taxation [10], using well-known empirical trends, that only low taxation stimulates economic development and vice versa - high taxation leads to forced loss of welfare; $h$ ) taking into account the need for optimal tax policy [11], which provides for optimal access to reproductive resources, use of working time and produce socially necessary products.

Not the least role in the development of the international financial system is played by innovative technologies. Today, more than 100 companies currently operate in the field of financial technologies in Ukraine, and more than half of them have started operations in the last three years. The most popular areas of work are payments and mobile wallets. According to the information contained in the Ukrainian Fintech Catalog 2019, 63\% of Ukrainian fintech companies are financed exclusively at their own expense and the same number have passed the break-even point. At the same time, $14 \%$ of companies have a staff of more than 75 people, which testifies to the prospects of this field and ample opportunities for job creation. $43 \%$ of Ukrainian fintech companies conquer the international market. And of those who work exclusively in Ukraine, $73 \%$ later intend to start working abroad [12].

Financial technologies are one of the main levers of digital transformation of the financial sector and increase of financial inclusion; The Ukrainian financial technology market is actively developing, and therefore, the country is moving in the right direction to simpler and more affordable financial services, a transparent economy and the involvement of more and more people in the modern financial system.

The development of financial technologies in the country is actively supported by the National Bank of Ukraine, its activities are aimed at the development of innovative financial services in Ukraine, namely, [12]:

- start of a fundamental update of the system of legislative regulation of the Ukrainian market of payments and funds transfer, which will include the implementation of the European directive PSD2 in national legislation, which will increase competition in the financial market and promote technology development;

- operation of the BankID NBU remote identification system, which simplifies the receipt of banking, financial and other commercial services;

- modernization of the NBU Electronic Payment System, which will make it possible to make payments in a format close to $24 / 7$ nationwide and using international standards IBAN and ISO 20022;

- protection of users of innovative solutions and products; it is about both cybersecurity and the protection of the rights of consumers of financial services. To this end, the National Bank announced the creation of a new mechanism for protecting the rights of consumers of financial services, which will provide for the responsibility of banks and non-bank financial institutions for the quality of their services;

- creation at the NBU of an Expert Council on Communication with Innovative Companies, which allows the regulator to understand the needs and directions of development of the fintech market, and innovative companies - the features of regulation and legislation on the scope of their activities. 
According to the World Bank, almost 2 billion people in the world are outside the formal financial system. Unfortunately, $37 \%$ of Ukrainians are among them [12]. Accordingly, the primary task of financial and technical market leaders is to inform people about the benefits of innovative technological solutions and their implementation in everyday life, ensuring effective cooperation between financial and technical companies and traditional banks to form a payment ecosystem and provide consumers with innovative, clear and secure solutions.

It is obvious that new technological achievements in the financial sphere are the result of human mental activity. But this result depends on the information space in which the person is. A certain analogy can be drawn between the well-known expression "we are what we eat" and the quality of human mental and economic activity. In other words, "we are what information we consume." That is, the quality of mental development and, consequently, its economic effectiveness, is currently significantly affected by changes in the information environment.

Today, the media industry is competing with each other for what kind of information and how to make it easier, more accessible to the consumer. This is done in order to facilitate the task of consuming information and implementing the necessary - marketing position. Such actions are based on physiological aspects of the human brain. Namely - the human brain is arranged in such a way that in the first place it perceives colorful information that requires a lot of energy and a lot of effort to process it. Proof of this is the intensified escalation of accessible and primitive content. That is, today humanity is undergoing a fundamental transformation of perception, and the formation of consciousness on its basis. Other owls, from the civilization of texts and inferences, man shifts his own efforts to the civilization of visual images, where there is no analytical and systematic thinking [5].

So, a young person, receiving information by different methods, using different sources from the outside world, is not just formed as a member of society, It is, in fact, programs its brain for further production in a particular area. At present, young people find themselves in a situation where a hyper informatized environment, full of content of different quality and orientation, is formed and continues to be complicated around them. First of all, it directly affects their ability to think.

Ashley Chen, a Korean researcher, provides very interesting empirical research that suggests that when a person activates the area of the brain responsible for identifying significance (structuring information), the brain systems responsible for thinking are suppressed [13]. This means that if a person constantly consumes new multidirectional information, he is constantly trying to structure it, while the energy of the brain for the area of thinking (analysis) does not come. That is, in fact, the brain goes into an inactive, inactive state. This is confirmed by the fact that people who are constantly in electronic social networks think stereotypically and stereotypically, without the ability to produce and generate their own ideas. If we talk about adolescents (Table 1), then according to research by Kaspersky Lab [14] $40 \%$ of children aged 3 to 10 years around the world are almost always online.

Table 1. Online nearly all time.

\begin{tabular}{|l|c|l|c|}
\hline \multicolumn{1}{|c|}{ Country } & Children under 10.\% & Country & Teenagers (14-18). \% \\
\hline Ukraine & 30 & Ukraine & 54 \\
\hline Japan & 55 & Japan & 74 \\
\hline Russia & 40 & Russia & 68 \\
\hline USA & 41 & USA & 60 \\
\hline Germany & 9 & Germany & 58 \\
\hline France & 7 & France & 32 \\
\hline All word & 40 & All word & $68 \%$ \\
\hline
\end{tabular}

Source: Research Kaspersky Lab, 2020 
As smartphones and other mobile devices become more common, 28\% of American adults now report that they go online "almost constantly," up from $21 \%$ in 2015 , according to a survey by the Pew Research Center from January 8 to February 7. 2020 (Fig. 1). Overall, $81 \%$ of Americans say they visit the Internet every day. This figure includes $28 \%$ who visit the Internet almost regularly, as well as $45 \%$ who say they visit the Internet several times a day, and $9 \%$ who visit the Internet about once a day. $8 \%$ visit the Internet several times a week or less, while $10 \%$ of adults say they do not use the Internet at all [15].

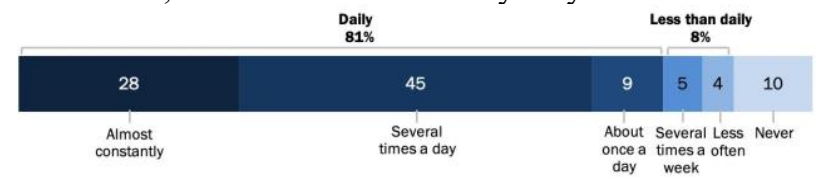

Fig. 1. Quantity of adults betraying online.

Source: survey conducted January 8 - February 9, 2020, [15]

It is especially likely that adults who have access to mobile communications spend much more time online. Among mobile Internet users, $86 \%$ of Americans use the Internet at least occasionally with a smartphone, tablet, or other mobile device, $92 \%$ visit the Internet daily and 32\% almost constantly. Younger adults are at the forefront of being constantly connected: about half of 18-29-year-olds (48\%) say they visit the Internet almost constantly, and $46 \%$ visit the Internet several times a day (Figure 2). By comparison, only $7 \%$ of those over 65 visit the Internet almost regularly, and $35 \%$ visit the Internet several times a day [15].

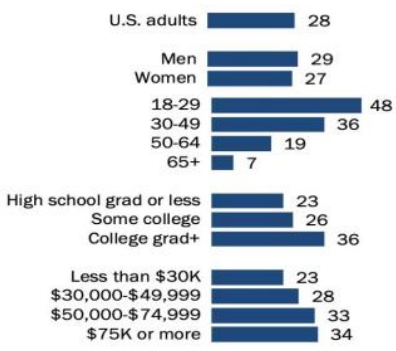

Fig. 2. Quantity of adults almost constantly online.

Source: survey conducted January 8 - February 9, 2020, [15]

Already in 1997, the amount of screen time (communication online, via smartphone) was equal to the amount of time when a person communicated with someone face to face. With the advent of the iPhone in 2007, the situation has become even more prevalent towards screen time, and in the future this trend is only intensifying. As a result, society is already facing a new problem of digital autism [16] - a condition in which people cannot maintain long-term psychological contact, are not interested in the inner world, and other people's problems when it is difficult to find verbal, nonverbal tools for direct interpersonal communication.

In fact, today, personalities in relation to each other become interchangeable, because people do not see the value of communicating with each other. What further complicates the situation is the loss of motivation and self-determination of further development and meaning of existence. Already, there is a change in the structure of social interaction (in particular, perceptions and reactions to people with disabilities), the lack of vertical management systems and the transition to a horizontal society leads to the fact that certain segments of the population lose learning skills [6]. That is, intense changes in communication methods lead to new negative trends in society - digital autism, reduced emotional intelligence and increased digital dependence. 
Based on the above, not only financial measures to address the effects of global development, but also incentives for mental development of society, in particular through digital monitoring, will create favorable conditions in Ukraine for reforms in the national economy in accordance with the requirements and challenges to which international relations must correspond. However, it should not be forgotten that improper implementation of any financial measures affects the behavior of society $[17,18]$ and its economic entities on all horizontals and verticals of management of the national economy. Therefore, failure to promote optimistic expectations of citizens, create additional financial risks, abnormal phenomena in the economy and reduce international business activity. New anomalies that are constantly emerging in the globalized economic system require the constant intensification of the structure of international relations, communications and information technology; servicing (service and support) of organizational, technological, administrative and legal components of international relations.

The prevailing global goal of hedonism [19], for pleasure, in the inability to build images of the future, leads to the fact that people become intolerant of their mistakes and expect quick and easy success. All this will not work best for the economy and civilization in general. The main problem is the atrophy of cognitive skills. Therefore, the rules of digital hygiene should become the legal norm of modern man.

It is impossible to ignore the problem of financial literacy of the population be ignored (Fig. 3). According to the OECD methodology, the general index of financial literacy of Ukraine is 11.6 (out of 21). This index is based on scores for financial knowledge, attitudes and behavior. The Ukrainian index is on a par with the lowest value among the 30 countries in the 2016 OECD survey, namely the Polish index (11.6). Ukraine's score is also slightly lower than the average (12.1) for the six low- and middle-income neighboring countries surveyed by the OECD (Belarus, Georgia, Hungary, Poland, the Russian Federation, and Turkey). The difference in results between Ukraine and other countries is explained by low scores for attitude and knowledge.

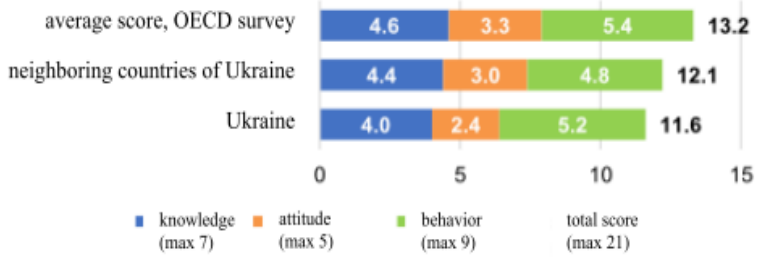

Fig. 3. OECD financial literacy score: comparison of Ukraine with other countries. Source: [3]

According to the results of the study, it is necessary to increase the financial culture of the population. Financial culture is the knowledge, skills and attitudes needed to ensure responsible financial behavior and increase the financial inclusion of Ukrainians. Its components are a whole set of cultures: tax, credit, pension, etc. Citizens of our country must share European values and be ready to live by European standards, be able to draw up their own budget, be responsible for their own financial decisions, engage in long-term financial planning, save, control their financial accounts, use loans wisely and manage debt. The main focus of improving financial culture is adolescents and young people aged 10 to 24 (Generation Z and Generation Alpha). The focus on young people dictates new approaches to learning, but it is this category that can act as agents of change who will teach their friends, parents, grandparents the financial knowledge and skills citizens need to make informed decisions and be responsible for their financial behavior.

In order to ensure further reform and development of the financial sector of Ukraine in accordance with best international practices and to ensure the implementation of measures provided for in the Association Agreement between Ukraine, of the one part, and the 
European Union, the European Atomic Energy Community and their Member States, of the other part, and also taking into account the completion in 2019 of the implementation of the Comprehensive Program for the Development of the Financial Sector of Ukraine until 2020, the financial sector regulators have developed and approved the Strategy for the Development of the Financial Sector of Ukraine until 2025. This strategy contains five strategic directions [20]:

- financial stability, which is realized through the improvement of supervisory approaches and the formation of transparency of the financial system, increasing its efficiency and resilience to shocks;

- macroeconomic development, which will be carried out through ensuring the stability of public finances, promoting lending to the economy, strengthening the protection of the rights of creditors and investors, creating conditions for attracting long-term resources;

- financial inclusion, namely increasing the availability and level of use of financial services, strengthening the protection of the rights of consumers of financial services, increasing the level of financial literacy of the population;

- development of financial markets by promoting the development of non-banking financial services, efficient capital market infrastructure, creation of liquid markets of financial instruments and mechanisms / instruments to reduce risks of financial transactions, integration of the financial market of Ukraine into the global financial space;

- innovative development through the development of an open architecture of the financial market and oversight, ensuring the development of the financial and technical market, digital technologies and regulatory platforms, as well as the digital economy.

Each direction contains strategic goals and indicators of their implementation, some of them are presented in Table 2.

Table 2. Some implementation indicators in the strategy for the development of the financial sector of Ukraine 2025.

\begin{tabular}{|c|c|c|c|}
\hline $\begin{array}{l}\text { Strategic } \\
\text { direction }\end{array}$ & Indicator & $\begin{array}{l}\text { The current indicator } \\
\text { value according to last } \\
\text { available date }\end{array}$ & $\begin{array}{l}\text { The target indicator } \\
\text { value on } 01.01 .2025\end{array}$ \\
\hline \multirow[t]{2}{*}{$\begin{array}{l}\text { Financial } \\
\text { stability }\end{array}$} & $\begin{array}{l}\text { Reducing the shadow } \\
\text { economy share }\end{array}$ & $30 \%$ of GDP & $\begin{array}{l}\text { Not more than } 20 \% \text { of } \\
\text { GDP }\end{array}$ \\
\hline & $\begin{array}{l}\text { Ensuring a transparent } \\
\text { ownership structure in } \\
\text { financial } \\
\text { participants }\end{array}$ & $\begin{array}{l}100 \% \text { transparency of } \\
\text { bank ownership structures. } \\
\text { It is not provided for other } \\
\text { participants in the } \\
\text { financial sector }\end{array}$ & $\begin{array}{l}100 \% \text { of participants in } \\
\text { the financial sector have } \\
\text { a transparent ownership } \\
\text { structure }\end{array}$ \\
\hline \multirow[t]{2}{*}{$\begin{array}{l}\text { Macroeconomic } \\
\text { development }\end{array}$} & Total public debt & $52,3 \%$ of GDP & $\begin{array}{l}\text { Not more than } 40 \% \text { of } \\
\text { GDP }\end{array}$ \\
\hline & $\begin{array}{l}\text { The penetration rate of } \\
\text { SME lending }\end{array}$ & $<1,9$ of GDP & $\begin{array}{l}\text { Not less than } 3 \% \text { до } \\
\text { ВВП }\end{array}$ \\
\hline \multirow[t]{2}{*}{$\begin{array}{l}\text { Financial } \\
\text { inclusion }\end{array}$} & $\begin{array}{l}\text { The level of public } \\
\text { confidence in the } \\
\text { financial system }\end{array}$ & $10 \%$ & $60 \%$ \\
\hline & $\begin{array}{l}\text { Index of the financial } \\
\text { literacy level of the } \\
\text { population }\end{array}$ & 11,6 & 12,5 \\
\hline \multirow[t]{2}{*}{$\begin{array}{l}\text { Development of } \\
\text { financial markets }\end{array}$} & $\begin{array}{l}\text { Insurance penetration } \\
\text { rate }\end{array}$ & $1,4 \%$ & $\begin{array}{l}\text { Not less than } 2 \% \text { of } \\
\text { GDP }\end{array}$ \\
\hline & $\begin{array}{l}\text { Introduced } \\
\text { infrastructure } \begin{array}{r}\text { bond } \\
\text { market, } \quad \text { including }\end{array}\end{array}$ & Not implemented & $\begin{array}{l}\text { Infrastructure bonds are } \\
\text { issued, including "green } \\
\text { bonds" in Ukraine }\end{array}$ \\
\hline
\end{tabular}




\begin{tabular}{|l|l|l|l|}
\hline & $\begin{array}{l}\text { "green bonds" in } \\
\text { Ukraine }\end{array}$ & \\
\hline $\begin{array}{l}\text { Innovative } \\
\text { development }\end{array}$ & $\begin{array}{l}\text { Implementation of new } \\
\text { payment standards and } \\
\text { formats (ISO 20022) }\end{array}$ & Not implemented & $\begin{array}{l}\text { New ISO 20022 } \\
\text { standards have been } \\
\text { introduced }\end{array}$ \\
\hline & $\begin{array}{l}\text { Introduction of Open } \\
\text { Banking standards on } \\
\text { the Ukrainian market }\end{array}$ & Not implemented & $\begin{array}{l}\text { At least 80\% of payment } \\
\text { service providers } \\
\text { provide the opportunity } \\
\text { to work in the Open } \\
\text { Banking format }\end{array}$ \\
\hline
\end{tabular}

Source: [20]

Special attention should be paid to potential and existing investors operating in Ukraine. It is proved that the investment decision-making process is influenced by many factors, in particular - macroeconomic shocks, official reports, the investor's own experience, his socio-demographic characteristics. In particular, Crego [21] in his publication demonstrated the dependence of investors' decisions on the content of weekly reports on the situation in the oil market. Thus, the study Malmendier U., Pouzo D., Vanasco V. [22] based on the OLG model proved a stable relationship between the composition of the investment portfolio and the demographic portrait of the investor.

Such features of investment behavior must be taken into account by the regulators of the financial system, designed to promote the creation of an attractive investment climate. Such structures include the National Commission on Securities and Stock Market, which in order to ensure the implementation of reforms in the field of capital markets, improve corporate governance and protect the rights of investors within this strategy focuses on: 1) introduction of new and development of existing financial instruments, as well as mechanisms for securitization of financial and other assets, as conditions for further development of the financial sector and ensuring the inflow of investments into the economy; 2) ensuring the implementation of state regulation of the stock market at the appropriate level in accordance with international standards, in particular, the requirements of European acts and standards of the International Organization of Securities Commissions (IOSCO), including the need to increase institutional and financial independence of the Ukrainian stock market regulator; 3) reforming the infrastructure of capital markets, including modernization, consolidation and development of exchange, settlement and clearing infrastructure of organized commodity markets and capital markets, ensuring improvement of the institution of financial sector intermediaries and rating agencies in accordance with European requirements.

The processes of Ukraine's integration into the world and European financial space require the development of its own special national model of economic development, which should be based on harmonization of the existing legal framework for the development of financial, banking and tax systems with European and international legislation. It is the direction for further research that should be done by the authors.

Today's global challenges reflect deep contradictions in political, economic, ideological and other spheres of socio-economic life, which requires the formation of new rules of conduct for various financial systems and the renewal of economic mechanisms. Currently, stabilization is possible through a timely response to various manifestations of complications through the creation of new institutional mechanisms and procedures that are consistent with the behavior of the financial market. It is necessary to take into account the impact on transformational changes in the country's economy of social and political spheres, mechanisms of identification of public interests and their optimal combination, consequences of political conflicts (and in Ukraine - consequences of hybrid war), migration (internal and external) and other results. dynamic transformations [23]. 
In modern Ukrainian economics, the deep essence of the financial system, Ukraine, its relationship with global financial and economic systems and patterns of their development are still insufficiently revealed [24, 25]. The interests of secure global economic development dictate the need for a new scientific approach to the study of the evolution of the global monetary and financial system, the world economy and international relations. The problem of reforming these systems in the direction of eliminating the separation of the Ukrainian financial system from the state of the real economy is especially acute. In such difficult circumstances, Ukraine's strategic orientation should be focused on multilateral global financial cooperation, a multifaceted basket of global currency (such as the dollar, euro, yuan) in full accordance with the general economic prospects and areas of international cooperation (USA, Europe, Asia). However, the consolidation and solidarity of the country's regions around these imperatives depends on creating favorable conditions for the development of economic initiative of citizens and entrepreneurship, implementation of the principles of democracy, fair distribution of national income, welfare, social assistance and other expectations in various global challenges.

\section{Conclusions}

In the future, it should be assumed that Ukraine needs unconventional solutions that do not copy the past, reproduce the concepts of catching up, and create opportunities to create more efficient and productive concepts of advanced development, based on the ideology of new technological breakthroughs, preservation and development of economic, intellectual and scientific and technological potential. In this context, it is important to fight for the right of freer access to the financial markets of the most developed countries, equal inclusion in global chains of relations in various spheres of international economic activity. The emphasis in mitigating the financial consequences of globalization should be placed on the fact that digitalization allows you to manage personal finances with greater efficiency than before. Most financial products and services are available online today, so you can see the graph of your expenses and income, buy and sell securities, open deposits, replenish the funded part of your pension that is, you can perform any actions related to managing your money right in your smartphone at any time, days and anywhere in the world. This opens up access to the widest range of investment proposals, however, and requires a certain financial culture and adherence to digital hygiene rules.

For Ukraine, local use of indicators of financial hedonism is possible. One of the promising directions in this area is the creation of an integral indicator of the quality of human life in a particular region, region or community. However, this approach requires a description of a wide range of indicators of socio-economic vital activity in the region, it needs the formation of high-quality statistics and an appropriate methodology for its processing.

Of course, for Ukraine, it is not possible to form and manage independent systems of internationalized reproduced cycles. But modern production and technology are today profitable only if the products created with their help on a global scale. Therefore, equal international cooperation is fundamentally important for Ukraine, based on guarantees of freer and less financially burdensome transfer of new technologies and elimination of all forms of discrimination of more developed countries in relation to Ukraine. It is these global challenges that require focusing on national issues, establishing and streamlining new high-tech links. 


\section{References}

1. Girschik, V. (2020). Managing Legitimacy in Business-Driven Social Change: The Role of Relational Work. Journal of Management Studies, 57(4), 775-804.

2. Graafland, J., Noorderhaven, N. (2020). Culture and institutions: How economic freedom and long-term orientation interactively influence corporate social responsibility. Journal of International Business Studies, 51, 1034-1043.

3. Financial Capability (2019, July). Financial literacy, financial inclusion and financial well-being in Ukraine. Retrieved from : https://www.fincap.org.uk/en/insights/financial-literacy--inclusion-and-wellbeing-inukraine

4. $\quad$ Ukraine 2030: Doctrine of balanced development (2017). Lviv: Kalvaria.

5. Gazzaeva, L. (2020). Report of Dr. A. Kurpatov in Davos 2020. Forbs. Finance and investment. Retrieved from : https://www.forbes.ru/finansy-i-investicii/

6. Dyck, A., Lins, K., Roth, L., Wagner, H. (2019). Do institutional investors drive corporate social responsibility? Journal of Financial Economics, 131(3), 693-714.

7. Maxton, G., Renders, J. (2016). Reinventing Prosperity. Managing Economic Growth to Reduce Unemployment Inequality, and a Climate Change. A Report to the Club of Rome. Kyiv: Pabulum.

8. Calinescu, T. (2012). Progressive taxation as form of social contract. Management and Education, 8(1), 171-175.

9. Chen, Sh., Guo, J. (2019). Progressive taxation as an automatic destabilizer under endogenous growth. Journal of Economics, 127, 47-71.

10. Hennessy, Ch., Kasahara, A., Strebulaev, A., Ilya, A. (2020). Empirical analysis of corporate tax reforms: What is the null and where did it come from? Journal of Financial Economics, 135(3), 555-576.

11. Bisceglia, M. (2020). Optimal taxation in a common resource oligopoly game. Journal of Economics, 129, 1-31.

12. National Bank of Ukraine (2019, June 15). Innovations and development of the fintech market of Ukraine are in the focus of the National Bank's attention. Retrieved from : https://bank.gov.ua/ua/news/all/innovatsiyi-ta-rozbudova-finteh-rinku-ukrayini-u-fokusi-uvagi-natsionalnogo-banku

13. Chen, A., Oathes, D., Chang, C., Bradley, T., Zhou, Z., Williams, L., Glover, G., Deisseroth, K., Etkin, A. (2013). Causal interactions between fronto-parietal central executive and default-mode networks in humans. In M. E. Raichle (Ed.), The Proceedings of the National Academy of Sciences (PNAS) (pp. 1-6). Washington: National Academy of Sciences.

14. Research Kaspersky Lab (2020, August 10). Teenagers online nearly all time Retrieved from : www.kaspersky.ru/about/news

15. Perrin, A. (2020, July 29). Adults say they are 'almost constantly' online. Pew Research Center. Retrieved from : https://www.pewresearch.org/facttank/2020/07/25/americans-going-online-almost-constantly/

16. Kurpatov, A. (2020, June 30). Why people are divided into stupid and smart. Retrieved from : https://maxpark.com/community/4391/content/7012898

17. Chhaochharia, V., Dasol, K., Korniotis, G., Kumar, M. (2019). Mood, firm behavior, and aggregate economic outcomes. Journal of Financial Economics, 132(2), 427-450.

18. Calinescu, T., Likhonosova, G., Zelenko, O. (2019). Manifestation Trend of the Behavioral Economy in Ukraine by the Integration Results. In K. S. Soliman (Ed.), Proceeding of the 33 International Business Information Management Association Conference (IBIMA) Education Excellence and Innovation Management through 
Vision 2020 (pp 2264-2273). Granada: International Business Information Management Association (IBIMA).

19. Soanes, C., Stevenson, A. (2009). Concise Oxford English Dictionary. New York: Oxford University Press.

20. Ministry of Finance of Ukraine (2020, January 16). Strategy of the financial sector of Ukraine until 2025. Government portal. Retrieved from : https://mof.gov.ua/storage/files/Strategija_financovogo_sectoru_ua.pdf

21. Crego, J. (2020). Why does public news augment information asymmetries? Journal of Financial Economics, 137(1), 72-89.

22. Malmendier U., Pouzo D., Vanasco V. (2020). Investor experiences and financial market dynamics. Journal of Financial Economics, 136(3), 597-622.

23. Calinescu, T., Likhonosova, G., Zelenko, O. (2018). Mechanism of Transformation Socio-Economic Potential of Ukraine: Tearing Away and Social Dialogue. In K. S. Soliman (Ed.), Proceeding of the 32nd International Business Information Management Association Conference (IBIMA) Vision 2020: Sustainable Economic Development and Application of Innovation Management from Regional expansion to Global Growth (pp. 949-965). Seville: Information Business Information Management Association (IBIMA).

24. Krynski, A., Kulishov, V., Gushko, S. (2015). Monetary and Financial Globalization: Advantages and Disadvantage. In Modern challenges of world economy development: Proceedings of the IV International scientific-practical conference (pp. 90-91). Kyiv: Taras Shevchenko National University of Kyiv.

25. Borzenko, O. O. (2019). Structural deformations in the world financial markets after the 1990s. Vinnytsia: LLC WORKS. 